\title{
Analisis Penerapan Etika Birokrasi Dalam Pelayanan Publik Pada Dinas Kependudukan Dan Pencatatan Sipil Kota Gunungsitoli
}

\author{
Yamolala Zega \\ Sekolah Tinggi Ilmu Ekonomi Pembangunan \\ yam_zega@yahoo.co.id
}

\begin{abstract}
Abstrak
Pelayanan dari para aparat birokrasi pemerintah Kota Gunungsitoli sangat diharapkan dapat melaksanakan penerapan etika birokrasi dalam pelayanan publik secara nyata sehingga tertib administrasi kependudukan dapat terwujud secara efektif dan efisien dengan tidak mengabaikan nilai-nilai moral dan etika birokrasi itu sendiri. Perumusan masalah yaitu bagaimana penerapan etika birokrasi dalam pelayanan publik pada dinas Kependudukan dan Pencatatan Sipil Kota Gunungsitoli. Jenis penelitian yang digunakan dalam penelitian ini adalah penelitian kualitatif. Dalam penelitian ini, peneliti mengambil sampel sebanyak 32 orang yaitu seluruh pegawai pada Dinas Kependudukan dan Pencatatan Sipil Kota Gunungsitoli. Jenis data yang digunakan yaitu data primer dan data sekunder. Kedua jenis data ini dapat diperoleh dengan cara observasi dan wawancara. Data yang sudah diperoleh maka akan di analisa dengan teknik analisa data dengan metode deduktif dan metode deskriptif. Dari hasil analisis secara deskriptif berdasarkan data sekunder yang diperoleh dari objek penelitian. Sebagaimana dijelaskan pada kajian teori, bahwa indikator Etika Birokrasi Dalam Pelayanan Publik adalah: Penerapan Etika Birokrasi: Kode etik dalam palayanan, Kejujuran dalam pelayanan, Tanggungjawab pelayanan, Disiplin dalam pelayanan, Diskriminatif pelayanan. Pelayanan Publik: Keterbukaan, Keserdehanaan, Kepastian, Keadilan, Keamanan dan kenyamanan, Perilaku petugas pelayanan.

Keywords Etika Birokrasi, Pelayanan Publik
\end{abstract}

\section{PENDAHULUAN}

Penyelenggaraan pelayanan publik hendaknya memenuhi syarat keetisan atau sesuai dengan normanorma etika yang berlaku. Dengan kata lain, norma etika dalam proses penyelenggaraan pelayanan publik benarbenar diterapkan. Penerapan etika birokrasi dalam proses pelayanan publik pada kantor pemerintah dengan pegawai negeri sebagai aparat publiknya, memang sudah selayaknya dilaksanakan, karena esensi dari pemberian pelayanan adalah memberikan kepastian dan kepuasan kepada pihak yang dilayani (pengguna jasa layanan). Etika dalam pelayanan publik diperlukan sebagai bentuk adanya sikap tanggap dari aparat birokrasi terhadap kepentingan masyarakat pengguna jasa.

Berdasarkan uraian tersebut, dapat dikatakan pengembangan etika dalam pelayanan publik sangatlah perlu dijadikan dasar bertindak oleh setiap aparat dalam menjalankan fungsi sebagai pelayan publik. Keputusan Menteri Negara Pendayagunaan Aparatur Negara (Meneg PAN) Nomor 63/KEP/M.PAN/7/2003, memberikan pengertian pelayanan publik yaitu segala kegiatan pelayanan yang dilaksanakan oleh penyelenggara pelayanan publik sebagai upaya pemenuhan kebutuhan penerima pelayanan maupun pelaksanaan ketentuan peraturan perundang undangan. Darwin (1999 : 24) mengartikan Etika adalah prinsip-prinsip moral yang disepakati bersama oleh suatu kesatuan masyarakat, yang menuntun perilaku individu dalam berhubungan dengan individu lain masyarakat. Contoh masalah yang sering terjadi sampai sekarang ini adalah terkadang saat ini dalam melayani masyarakat harus ada balas jasa berupa uang atas jasa yang di berikan kepada pengguna jasa, baru dilayani semaksimal mungkin, pelayan berperilaku ramah dalam melayaninya dan terkadang jika berkas tidak lengkap dianggap lengkap saja karena sudah diberikan penyemangat/ berupa uang minum dari pengguna jasa tapi jika tidak 
ada berupa penyemangat maka berkas itu harus lengkap, kalau tidak ngak akan diproses. Hal seperti ini yang harus dilakukan perubahan dalam melayani masyarakat, melayani harus sesuai dengan peraturan yang belaku, jangan karena melihat penyemangat (uang) dari masyarakat maka aturan yang telah ditetapkan bisa saja ditiadakan. Pelayanan dari para aparat birokrasi pemerintah Kota Gunungsitoli tentulah sangat diharapkan dapat dilaksanakan secara nyata sehingga tertib administrasi kependudukan dapat terwujud secara efektif dan efesien dengan tidak mengabaikan nilai-nilai moral dan etika birokrasi itu sendiri.

\section{LANDASAN TEORI 1. Pengertian Etika}

Etika berasal dari bahasa Yunani, Ethos yang berarti kebiasaan atau watak dan dalam bahasa prancis disebut etiquet atau etiket yang dapat diartikan sebagai kebiasaan atau cara bergaul dan berperilaku yang baik. Secara konsep, etika dipahami sebagai "suatu sistem nilai yang mengatur mana yang baik dan mana yang buruk dalam suatu kelompok atau masyarakat". Wahyudi (2008: 8) mengemukakan bahwa etika (ethics) merupakan salah satu cabang filsafat moral atau pembenaran-pembenaran filosofis (philosophcaljudgement). Moral juga bisa merupakan suatu instrumen dalam suatu masyarakat, apabila suatu kelompok sosial menghendaki tuntunan bertindak untuk segala pola tingkah laku yang disebut moral.

Akan tetapi moral memiliki pertimbangan lebih tinggi dalam menentukan kebenaran dan keharusan. Sekalipun dalam penerapan sangsi atas pelanggaran moral terhadap pelanggarnya tidak memperlakukan tindakan paksaan secara fisik seperti dihukum dalam penjara, tetapi lebih kepada sangsi sosial seperti rasa bersalah, malu, merasa terkecilkan oleh komunitas dan sangsi verbal lainnya. Jadi moral kadang-kadang bisa berwujud seakan akan hukum yang harus ditaati tetapi juga sebagai konvensi. Moral dalam pengertian umum yang sering kita lihat, lebih menekankan kepada karakter dan sifat individu yang khusus akan tetapi, kondisi khusus itu bersifat baik, akan tetapi sifat baik dimaksud tidak dilandasi/ditentukan oleh perasaan ketaatan/terhadap peraturan, Seperti dalam kasus murah hati, kasih sayang, empati, berjiwa besar dan sebagainya. Itu semua dilakukan seseorang bukan karena taat atas peraturan tetapi karena kesadaran sendiri, yang didorong oleh hati nuraninya. Dengan kata lain moral merupakan pendorong seseorang untuk melakukan tindakan baik seakan-akan sebagai kewajibannya, karena itu moral dapat menjadi parameter (alat ukur) tindakan "baik/buruk".

K. Bertens (2007 : 6) memberikan pemahanan tentang etika atas tiga bentuk yaitu; Pertama, etika bisa dipakai dalam arti nilai-nilai dan norma-norma. Moral yang menjadi pegangan bagi seseorang atau kelompok dalam mengatur tingkah laku. Dapat kita katakan sebagai "sistem nilai". Kedua etika dapat diartikan sebagai kumpulan azas atau nilai moral yang dimaksud disini "kode etik". Ketiga, etika mempunyai arti ilmu tentang yang baik dan buruk.

\section{Pengertian Etika Birokrasi}

Menurut Yahya Muhaimin Birokrasi adalah keseluruhan aparat pemerintah, baik sipil maupun militer yang bertugas membantu pemerintah (untuk memberikan pelayanan publik) dan menerima gaji dari pemerintah karena statusnya itu, sedangkan Hegel melihat, bahwa birokrasi merupakan jembatan yang dibuat untuk menghubungkan antara kepentingan masyarakat dan kepentingan negara yang dalam saat-saat tertentu berbeda. Oleh sebab itu peran birokrasi menjadi sangat strategis dalam rangka menyatukan persepsi dan perspektif antara negara (pemerintah) dan masyarakat sehingga tidak terjadi kekacauan.

Darwin (1999 : 24) juga mengartikan Etika Birokrasi (Administrasi Negara) adalah sebagai seperangkat nilai yang menjadi acuan atau penuntun bagi tindakan manusia dalam organisasi. Dengan mengacu kedua pendapat ini, maka etika mempunyai dua fungsi, yaitu pertama sebagai pedoman, acuan, referensi bagi administrasi negara (birokrasi publik) dalam menjalankan tugas dan kewenangannya agar tindakannya dalam birokrasi sebagai standar penilaian apakah sifat, perilaku, dan tindakan birokrasi publik dinilai baik, buruk, tidak tercela, dan terpuji. Seperangkat nilai dalam etika birokrasi yang dapat digunakan sebagai acuan, referensi, penuntun, bagi birokrasi publik dalam menjalan tugas dan kewenangannya antara lain, efisiensi, membedakan milik pribadi dengan milik kantor, impersonal, merytal sistem, responsible, accountable, dan responsiveness.

\section{METODOLOGI PENELITIAN}

Lokasi penelitian adalah pada kantor Dinas Kependudukan dan Pencacatan Sipil Kota Gunungsitoli. Jenis penelitian yang digunakan dalam penelitian ini adalah penelitian kualitatif. Salim (2001:5) mengatakan penelitian kualitatif merupakan suatu metode berganda dalam fokus, yang melibatkan suatu pendekatan yang interpretatif dan 
wajar terhadap setiap pokok permasalahannya. Ini berarti, penelitian kualitatif bekerja dalam setting yang alami yang berupaya untuk memahami, memberi tafsiran pada fenomena yang dilihat dari arti yang diberikan orang-orang kepadanya. Di dalam melakukan penelitian, populasi sangat penting sekali karena, merupakan sasaran yang akan diteliti. Menurut pendapat Sugiyono (2006 : 55) bahwa : "populasi adalah wilayah generalisasi yang terdiri atas objek atau subjek yang mempunyai kualitas dan karakteristik tertentu yang akan ditetapkan oleh peneliti untuk dipelajari dan kemudian ditarik kesimpulan". Oleh karena itu, yang menjadi populasi dalam penelitian ini adalah seluruh pegawai yang ada pada Kantor Dinas Kependudukan dan pencatatan Sipil Kota Gunungsitoli sebanyak 32 orang.Sampel adalah sebagian atau mewakili populasi yang akan diteliti. sampel memiliki peranan dalam penelitian ini dalam rangka memperoleh data yang di teliti. Menurut suarsimi (1993 : 120), mengatakan bahwa : "apabila subjek kurang dari 100, lebih baik diambil semua, sehingga penelitian merupakan penelitian populasi, selanjutnya jika subjek lebih besar dapat di ambil antara 10\%-15\% atau 10\%-25\% atau lebih". Mengingat jumlah populasi tidak banyak, maka seluruh populasi penelitian sekaligus menjadi sampel sebanyak 32 orang. Menurut Arikunto (2007 : 309) : "Penelitian deskriptif adalah penelitian yang dimaksudkan untuk mengumpulkan mengenai status suatu gejala yang ada, yaitu keadaan gejala menurut apa adanya saat penelitian dilakukan".

\section{HASIL PENELITIAN}

Sesuai dengan penjelasan pada bab sebelumnya, bahwa yang menjadi sampel sekaligus sebagai responden pada penelitian ini adalah seluruh pegawai pada Dinas Kependudukan dan Pencatatan Sipil Kota Gunungsitoli yang berjumlah 36 (tiga puluh enam) orang. Maka oleh karena itu, penulis dapat menguraikan karakteristik responden berdasarkan jenis kelamin, pendidikan terakhir serta golongan dan pangkat, sebagai berikut :

\section{Jenis Kelamin}

Gambaran responden penelitian, akan penulis uraikan berdasarkan jenis kelamin, sebagai berikut :

Tabel 4.1

Daftar Responden berdasarkan Jenis Kelamin

\begin{tabular}{|c|l|c|}
\hline No. & Jenis Kelamin & Jumlah \\
\hline 1. & Laki-laki & 17 orang \\
\hline 2. & Perempuan & 15 orang \\
\hline \multicolumn{2}{c}{ o $\boldsymbol{t} \boldsymbol{a} \boldsymbol{l}$} & 32 orang \\
\hline
\end{tabular}

Sumber : Dinas Kependudukan dan Pencatatan Sipil Kota Gunungsitoli 2017 


\section{Tingkat Pendidikan}

Selanjutnya, penulis akan menyajikan karakteristik responden berdasarkan pendidikan terakhir, sebagai berikut :

Tabel 4.2

Daftar Responden berdasarkan Pendidikan Terakhir

\begin{tabular}{|c|c|c|}
\hline No. & Pendidikan Terakhir & Jumlah \\
\hline 1. & SMA & 3 Orang \\
\hline 2. & SLTA & 6 Orang \\
\hline 3. & Diploma & 7 Orang \\
\hline 4. & Sarjana & 15 Orang \\
\hline 5. & Pascasarjana & 1 Orang \\
\hline & Total & 32 orang \\
\hline
\end{tabular}

Sumber : Dinas Kependudukan dan Pencatatan Sipil Kota Gunungsitoli 2017

\section{Golongan dan Pangkat}

Kemudian, karakteristik responden berdasarkan golongan dan pangkat, sebagai berikut :

Tabel 4.3

Daftar Responden berdasarkan Golongan dan Pangkat

\begin{tabular}{|c|c|c|}
\hline No. & Gol. dan Pangkat & Jumlah \\
\hline 1. & IV/a & 1 orang \\
\hline 2. & $\mathrm{IV} / \mathrm{b}$ & 1 orang \\
\hline 3. & $\mathrm{IV} / \mathrm{c}$ & 1 orang \\
\hline 4. & III/a & 4 orang \\
\hline 5. & $\mathrm{III} / \mathrm{b}$ & 4 orang \\
\hline 6. & $\mathrm{III} / \mathrm{c}$ & 6 orang \\
\hline 7. & $\mathrm{III} / \mathrm{d}$ & 3 orang \\
\hline 8 & II/a & 1 orang \\
\hline 9 & $\mathrm{II} / \mathrm{b}$ & 3 orang \\
\hline 10 & $\mathrm{II} / \mathrm{c}$ & 4 orang \\
\hline 11 & $\mathrm{II} / \mathrm{d}$ & 4 Orang \\
\hline \multicolumn{2}{|r|}{ Total } & 32 orang \\
\hline
\end{tabular}

Sumber : Dinas Kependudukan Dan Pencatatan Sipil Kota Gunungsitoli 2017

Berdasarkan pasal 40 Ketentuan Peralihan Peratuan Walikota Gunungsitoli No. 03 tahun 2009 tentang organisasi dan Tata Kerja Dinas-Dinas Daerah Kota Gunungsitoli ditegaskan bahwa uraian Tugas, Fungsi dan Tata Kerja di Lingkungan Organisasi Dinas-Dinas Daerah akan diatur dan ditetapkan dengan Perataran walikota. Sebagaimana yang dimaksud diatas, maka perlu menetapkan Peraturan Walikota tentang Uraian Tugas, Fungsi dan Tata Kerja Pada Dinas Kependudukan dan Pencatatan Sipil Kota Gunungsitoli.

Dari temuan penelitian diatas, maka penulis akan melakukan analisa secara deskriptif berdasarkan data sekunder yang diperoleh dari objek penelitian. Sebagaimana dijelaskan pada kajian teori, bahwa indikator Etika Birokrasi Dalam Pelayanan Publik adalah : Penerapan Etika Birokrasi: Kode etik dalam palayanan, Kejujuran dalam pelayanan, Tanggungjawab pelayanan, Disiplin dalam pelayanan, Diskriminatif pelayanan. Pelayanan Publik: Keterbukaan, Keserdehanaan, Kepastian, Keadilan, Keamanan dan kenyamanan, Perilaku petugas pelayanan. 


\section{KESIMPULAN}

Berdasarkan pada hasil analisis terhadap Penerapan etika birokrasi dalam pelayanan publik pada Dinas Kependudukan dan Pencatatan Sipil Kota Gunungsitoli dapat disimpulkan sebagai berikut ini :

1. Secara umum bahwa Penerapan etika birokrasi dalam pelayanan publik di Indonesia kurang dibahas secara luas dan tuntas sebagaimana terdapat di negara maju, meskipun telah disadari bahwa salah satu kelemahan dasar dalam pelayanan publik di Indonesia adalah masalah moralitas. Etika sering dilihat sebagai elemen yang kurang berkaitan dengan dunia pelayanan publik. Padahal, dalam literatur tentang pelayanan publik dan administrasi publik, etika merupakan salah satu elemen yang sangat menentukan kepuasan publik yang dilayani sekaligus keberhasilan organisasi pelayanan publik itu sendiri.

2. Penerapan etika birokrasi dalam pelayanan publik pada Dinas Kependudukan dan Pencatatan Sipil Kota Gunungsitoli, sebagaimana ditunjukkan oleh penelitian ini cukup baik dari harapan pada umumnya. Hal ini, menunjukkan aparat birokrasi mampu mewujudkan misi organisasi dari aturan yang ditetapkan dalam pemberian pelayanan kepada publik. Oleh karena itu, timbul kepuasan masyarakat sebagai pengguna jasa yang nampak pada keluhan yang disampaikan dalam hal pelayanan KTP. Dengan demikian, secara umum kesadaran aparat birokrasi pada Dinas Kependudukan dan Pencatatan Sipil Kota Gunungsitoli, berdasarkan dalam pengembangan etika birokrasi dalam pelayanan publik sudah berusaha semaksimal mungkin dalam melakukan pelayanan publik.

3. Perilaku aparat birokrasi terhadap Penerapan etika birokrasi dalam organisasi pada Dinas Kependudukan dan Pencatatan Sipil Kota Gunugsitoli saat ini, mampu menetapkan tapal batas untuk membedakan dengan birokrasi lain.

\section{UCAPAN TERIMA KASIH}

Dalam hal ini peneliti mengucapkan terima kasih kepada pihak-pihak yang telah mendukung dalam proses penyelesaian penelitian ini antara lain :

1) Seluruh Bapak dan Ibu Dosen yang mengajar di STIE Pembnas Nias yang telah mendukung penulis dalam memperoleh data.

2) Istri tercinta Tiesda Zai, S.E dan beserta anak yang selalu memberikan cinta, kasih sayangnya, dan dukungan yang begitu berarti serta selalu menemani dalam suka maupun duka dari awal sampai akhir perjalanan sejak perkuliahan.

3) Semua pihak yang telah membantu dalam proses penyelesaian penelitian ini.

\section{DAFTAR PUSTAKA}

Arinkunto, Suharsimi, 2007. Prosedur penelitian suatu pendekatan praktis, Jakarta: PT. Rineka cipta.

Dwiyanto, Agus dkk., 2003, Reformasi Tata Pemerintahan dan Otonomi Daerah, Yogyakarta: Universitas Gadjah Mada.

Darwin, 1999 Tata Pemerintahan menuju politik orde baru, Jakarta: Rineka Cipta

Faisal, Sanapiah, 2001. Format-Format Penelitian Sosial, Raja Grafindo Persada, Jakarta.

Hasan, Iqbal, 2009. Analisa Data Penelitian Dengan Statistika. Jakarta: Bumi Aksara.

K. Bartens, 2007. Etika, Gramedia Pustaka Utama, Jakarta.

Nazir Mohamad., 1995. Metode Penelitian, Jakarta, Ghalia

Nazir, Mohamad., 1999. Metode Penelitian, Cetakan Ketiga, Jakarta, Ghalia Indonesia

Nawawi, Hadari, 2003. Metode Penelitian Bidang Sosial, Gadjah Mada University Press, Yogyakarta.

Ryaas, Rasyid, 1997. Birokrasi Pemerintahan Politik Orde Baru, Yasrif Watampone Jakarta.

Ryaas, Rasyid, 1998. Desentralisasi Dalam Menunjang Pembangunan Daerah Dalam Pembangunan Administrasi di Indonesia, PT. Pustaka LP3ES, Jakarta.

Surakhmad, Winarno, 1982. Pengaturan Penelitian Ilmiah Dasar Metode Dan Teknik, jakarta: Tarsito.

Salim, Agus, 2001. Perubahan Sosial, Bumi Aksara, Jakarta.

Salim, 2007. Penelitan Kualitatif. Jakarta : Rineka Cipta.

Suharsimi, 1993. Prosedur Penelitian, Edisi Keempat. Jakarta: Rineka Cipta.

Wahyudi, Kumorotomo, 2008. Etika Administrasi Negara, RajagrafindoPersada, Jakarta. 